\title{
Marginaliserade människors upplevelse av rasism Migranters och etniska minoriteters erfarenheter av arbete i europeisk äldreomsorg
}

Nina Sahraoui

\begin{abstract}
Introduktion
Om du ser någon förtrycka någon annan måste du säga ifrån, och om du inte kan göra något måste du ta ställning mot det inombords. Men om du bara sitter bredvid och tittar på så gör det också dig till en syndare. Fattar du? Om du utstår förtryck och inte gör motstånd begår du också en stor synd. Därför måste vi alltid göra motstånd, vi måste. Var du än befinner dig så är livet inte lätt. Det är alltid, alltid en kamp. Det kommer att göra dig starkare. Hur är det med dig, är du en kämpe? (Sameera, 32, Mauritius, London)
\end{abstract}

När vi träffades hade Sameera levt i Storbritannien i tolv år. Hon kom från Mauritius, där hon hade arbetat på ett apotek. När hon anlände till Storbritannien fick hon jobb på ett apotek, men i en lägre befattning. Under fyra år hade hon inte en enda dags ledighet. Hon kände sig utmattad, sade upp sig och började leta efter något annat. Hon fick en tjänst som sjukvårdsbiträde på ett äldreboende. På sitt nya jobb upplevde hon andra svårigheter: hon trakasserades av sina arbetskamrater och upplevde att hon blev diskriminerad av sin chef. Sameera fällde ovanstående replik när hon var försjunken i dessa obehagliga minnen. Om den betraktas som ett uttryck för en individuell erfarenhet fram- 
står Sameeras berättelse som personlig och specifik. Om den däremot analyseras som en del i en institutionell kontext, formad av arbetsrätt, migrationspolitiska antidiskrimineringslagar och -praktiker, skildrar en berättelse av detta slag erfarenheter av skiftande former av institutionell rasism. Att konfronteras med rasism är en del av arbetslivets vardagliga ojämlikheter. Rasismens funktioner är inte bara sammanvävda med socioekonomiska ojämlikheter utan är en essentiell del av dem, vilket har belagts i tidigare forskning om hur arbetsmarknaden differentieras utifrån genus och rasifiering (Samers 2008).

Genom att analysera hur utomeuropeiska migranter och medlemmar av etniska minoriteter som arbetar inom sjukvårdssektorn skildrar sina erfarenheter och upplevelser av rasism och diskriminering inom äldreomsorgen i London, Paris och Madrid, visar jag i detta kapitel att antidiskrimineringslagstiftningen ofta är oåtkomlig för rasifierade människor i prekära yrken. Arbetskraftens rasifiering inom omsorg och hushållsnära tjänster har utforskats i många etnografiska studier, vilka ofta fokuserat på hushållsarbete utfört i arbetsgivarens privata bostad (Anderson 2000; Marchetti 2014; Scrinzi 2013). Detta kapitel bidrar med ytterligare förståelse genom att också inkludera vårdhem och undersöka vårdarbetarnas erfarenheter av rasism $i$ ett institutionellt sammanhang.

Efter en kort beskrivning av studiens metodologi situerar jag i den första delen av kapitlet begreppen "rasism", "rasifiering" och "rasistisk diskriminering", så som jag använder dem i detta sammanhang. Jag avhandlar också i korthet de politiska antidiskrimineringsstrategier som implementerats i de tre länder som behandlas i kapitlet. Denna översiktliga beskrivning kontextualiserar de specifika miljöer där erfarenheter av rasism och diskriminering utspelar sig. I den andra delen av texten utforskar jag empiriska fall av rasistiskt bemötande från kollegor och trakasserier eller diskriminering från arbetsgivare. Eftersom samtida uttryck för rasism i mellanmänskliga relationer ofta är mindre uppenbara blir offren för rasism osäkra på om och hur de kan bemöta sådana former av rasism. I de fall som jag har studerat kunde arbetsledarna dessutom ofta tolerera uttryck för rasism, eller sluta upp bakom den dominerande gruppen. I denna del utforskar jag också arbetsledarnas agerande, som emellanåt kunde vara direkt diskriminerande på olika sätt, från orättvis arbetsfördelning till mobbning och stigmatisering. I 
den sista delen av artikeln utforskar jag hur arbetarna hanterade rasism och rasistisk diskriminering och varför dessa situationer ofta var särskilt svåra att bemöta med rättsliga medel.

\section{Metodologi}

Kapitlet grundar sig på fältarbeten genomförda i London, Paris och Madrid mellan december 2013 och januari 2015. Det är tre urbana centrum av betydande storlek, som i många avseenden har drabbats osedvanligt hårt av det moderna samhällets "vårdkris" (Fraser 2016). Samtidigt är dessa tre platser underkastade olikartade migrations-, arbetslivs- och omsorgsregimer (Williams 2012, se nedan).

De slutsatser som jag presenterar bygger på 83 intervjuer med utomeuropeiska migranter och medlemmar av etniska minoriteter som arbetar i äldreomsorgen i dessa tre europeiska huvudstäder. Även om utomeuropeiska migranter och etniska minoriteter möter olika rasifieringsprocesser i arbetslivet är det motiverat att sammanföra dessa två grupper i en studie av postkolonial migration, eftersom de tillsammans belyser en historisk kontinuitet som ett ensidigt fokus på migrantarbetare skulle förbise.

I London kom deltagarna från Filippinerna (8), Bangladesh (2), Indien (2), Somalia (2), Mauritius (2), Kina (1), Rwanda (1), Nigeria (1), Uganda (1), Ghana (1) och Sierra Leone (1), och tre av dem var födda i Storbritannien. I Paris kom deltagarna från Kamerun (6), Elfenbenskusten (4), Senegal (4), Guinea (2), Algeriet (1), Tunisien (1), Marocko (1), Myanmar (1) och de franska departementen Guadeloupe, Martinique och Réunion (8), och två var födda i franska storstäder. I Madrid kom deltagarna från Ecuador (11), Peru (5), Colombia (2), Marocko (2), Kamerun (1), Nicaragua (1), El Salvador (1), Kap Verde (1), Paraguay (1) och Kuba (1), och en var född i Spanien.

Även om jag berör vissa skillnader mellan hur rasism i arbetslivet yttrar sig i de tre städerna, så fokuserar jag främst på att finna kopplingar mellan respondenternas erfarenheter för att förstå de gemensamma mönster som kapitlets övergripande argument vilar på. Berättelserna från de tre platserna behandlas i skiftande utsträckning i kapitlets tematiska sektioner. Det avspeglar att olika teman framträdde i varierande 
grad på olika platser. Genom att utgå från respondenternas erfarenheter bidrar detta analytiska perspektiv till att blottlägga hur olika regimer interagerar.

Termen "välfärdsregim" är ursprungligen hämtad från Gøsta Esping-Andersen (1990/2013) och avser, med Lutz formulering, "den sociala politikens och praktikens samverkande organisatoriska och kulturella koder genom vilka relationen mellan olika aktörer (staten, arbetsmarknaden och familjen) artikuleras och förhandlas" (Lutz 2008). En omsorgsregim innefattar "kluster av politiska strategier, praktiker, traditioner, diskurser, sociala relationer och konfliktytor" (Williams 2012, 371). Med utgångspunkt i Fiona Williams (2014, 17, kursivering i originaltexten) betonar jag hur olika regimer artikuleras: "ett lands omsorgsregim interagerar med dess migrationsregim och dess arbetslivsregim vilket skapar det institutionella sammanhang som formar hur de migrantkvinnor som arbetar med vård och omsorg och deras chefer upplever sin situation, liksom även de mönster av migration och omsorgsarbete som finns i olika länder." En migrationsregim omfattar både "regulativa och mobila migrationspraktiker" (Rass \& Wolff 2018, 22). I begreppet "omsorgsregim" innefattar Fiona Williams både migrationspolitik, nationella normer och praktiker som styr relationer mellan majoritets- och minoritetsgrupper, migranters mobilisering samt relevanta nationella och transnationella historier (Williams 2012, $371 \mathrm{ff}$.).

Även om detta kapitel fokuserar på rasism behöver dess relation till genus belysas (se Sahraoui 2019). Det är föga förvånande att merparten av respondenterna i alla tre länderna var kvinnor, men könsfördelningen varierade: i London var det 19 kvinnor och 6 män; I Paris 26 kvinnor och 4 män; i Madrid 23 kvinnor och 4 män. I samtida europeiska samhällen uppfattas omsorgsarbete alltjämt som en kvinnosyssla och ett kall (Folbre 2012). Feministiska sociologer har dekonstruerat distinktionen mellan offentligt och privat, utforskat dess funktion i patriarkala, kapitalistiska samhällen och blottlagt dess betydelser för könsrelationer (Delphy 2013; Federici 2012). Överrepresentationen av kvinnor i sjukvårdssektorn - 84 procent i île-de-France (Pardini 2013); 87,9 procent i Storbritannien och över 90 procent i Spanien (León 2010) - är en konsekvens av djupt rotade kulturella normer. Oaktat de marginella skillnaderna mellan länderna 
återspeglar denna massiva kvinnodominans inom vårdyrkena könsrollernas sociala betydelse och inverkan på arbetsmarknadens uppdelning.

I Storbritannien och Spanien arbetade informanterna som sjukvårdsbiträden (i vissa fall bodde de i vårdtagarnas hemmiljö). I Frankrike motsvaras denna position av tre olika yrkesroller med olika dagliga arbetsuppgifter: personlig assistent (auxiliaire de vie), vårdbiträde (aide médico-psychologique) och sjukvårdsassistent (aide-soignant). I London arbetade alla respondenterna på privata sjukhem. I Paris och Madrid var en minoritet av respondenterna anställda av privata företag som erbjuder hemsjukvård eller direkt av vårdtagarnas familjer ( 5 respektive 8 personer) medan merparten var anställda av privata sjukhem (25 respektive 19 personer). Jag genomförde intervjuerna på caféer och på sjukhemmen, vanligtvis bakom stängda dörrar. Vid mina besök på sjukhem stannade jag vanligtvis i flera timmar, tog in arbetsplatsens atmosfär och observerade hur det dagliga arbetet sköttes i korridorer och allmänna utrymmen. De respondenter jag intervjuade på arbetsplatsen valdes ut slumpmässigt och de jag träffade utanför arbetsplatsen kontaktades genom snöbollsurval. Intervjuerna kunde vara i mellan 35 minuter och över två timmar, men pågick oftast i omkring en och en halv timme. Alla intervjuer spelades in och transkriberades. Intervjuguiden inkluderade en fråga om rättvisa på arbetsplatsen och de flesta erfarenheter av rasism återgavs som svar på denna fråga, men respondenterna kunde också föra rasism på tal i anslutning till frågor om sitt välbefinnande på jobbet eller i allmänhet. Efter den tematiska analysen använde jag mjukvara för kvalitativ dataanalys för att koda och analysera den insamlade datan (Boyatzis 1998).

\section{Rasifiering, institutionell rasism och politiska antidiskrimineringsstrategier}

I linje med den intersektionella forskningens idéer om interkategoriell komplexitet (McCall 2005) gör jag i detta kapitel strategiskt bruk av begreppet "etnisk minoritet" (Aspinall 2002). Begreppen "rasifieringsprocess" och "rasifierade grupper" är å andra sidan att föredra för att fånga de sociala processerna i fråga, eftersom det inte ger "etnicitet" eller "ras" materiell existens men ändå beaktar deras sociala betydelse i kampen 
för erkännande och som uttryck för särskilda former av förtryck. Produktionen av rasifiering, såväl som den diskriminering och ojämlikhet som emanerar ur den, kan hänvisa till "ras", "etnicitet", kultur, religion, nationalitet eller andra socialt konstruerade kategorier. Robert Miles hävdar att termen "rasifiering" är att föredra framför termen "ras", eftersom den bygger på en förståelse av "ras" som socialt konstruerat (Miles 1993). Rasifiering är en process, och det finns ingen fast definition av vad som utgör rasism. "Rasism är inte en statisk mänsklig egenskap som bara väntar på att utlösas under gynnsamma omständigheter", skrev Stuart Hall $(1978,26)$. Gilroy varnar på ett liknande sätt för tolkningar som inte erkänner att rasism "existerar i pluralis, och jag har hävdat att den kan förändras och anta olika former och uttrycka olika politiska relationer" (Gilroy 1987/2002, 42). Balibars föreställning om ett "totalt socialt fenomen" belyser vidare att rasism återfinns i vardagliga praktiker, diskurser och föreställningsvärldar (Balibar \& Wallerstein 1988). Rasistisk diskriminering är att betrakta som en praktik, vilket skiljer den från rasism, som kan ta sig ett brett spektrum av möjliga uttryck. Rasistisk diskriminering är ett av dessa uttryck.

Förhållandet mellan ideologi och praktik, eller frågan om uppsåt, måste också förtydligas. Fram till 1970-talet tenderade den brittiska sociologiska "rasrelationsmodellen" att fokusera på personliga fördomar. På liknande sätt tenderade filosofiska tolkningar av rasism att basera definitionen av rasism på frågan om uppsåt, exempelvis genom att hänvisa till "målmedveten rasism" (Headley 200o). Detta kapitel vilar emellertid inte på det antagandet. Med stöd hos Anthias och Yuval-Davis antar jag i stället att "rasistiska praktiker inte förutsätter ett strukturerat rasistiskt uppsåt [...]. Praktiker kan vara rasistiska i sina konsekvenser" (1992, 13). I korthet kan rasistisk diskriminering uppstå ur politiska strategier och praktiker som kanske, eller kanske inte, är präglade av rasistisk ideologi. I detta avseende är begreppet "institutionell rasism" - som är mer framträdande i anglosaxisk litteratur än i franska eller spanska studier av rasism - särskilt användbart för att förstå rasistiska konsekvenser utan systematiska rasistiska uppsåt.

Tidiga tankar om institutionell rasism återfinns i Black Power-rörelsen, och särskilt i Carmichaels författarskap (Carmichael \& Hamilton 1967/1992). Senare skilde Sivanandan (1985) mellan vad han kallade"rasi- 
alism", definierat som fördomar som individer uttryckte, och "rasism", med vilket han menade strukturell rasism. Som Ikuenobe (2010, 162) hävdar vilar detta rasistiska förtryck på maktförhållanden: "All slags rasdiskriminering eller fördomar kan inte betecknas som rasism. För att rasdiskriminering eller fördomar ska kunna definieras som rasism måste de innefatta ett socialt och politiskt maktförhållande." Jag analyserar de rasifierade arbetarnas levda erfarenheter som rasistiska mot bakgrund av att "xenofobi, eller motviljan mot främlingen eller utbölingen, [...] blir rasistisk när maktförhållanden är inblandade. Dessa kan omsätta känslan av antipati i praktik och skapa rasistiska konsekvenser" (Anthias \& Yuval-Davis 1992, 12).

Antagandet att vi lever i ett samhälle bortom rasdistinktioner döljer det faktum att "ras" fortlever som en organiserande dynamik i europeiska samhällen. Den västerländska världens politiska ekonomi formas i allt större utsträckning av nyliberala värden, och under nyliberal governmentalitet "förväntas alla ta fullt personligt ansvar" och riskerar att "förlora sina rättigheter om de lever sitt liv på ett felaktigt sätt" (Lentin \& Titley 2011, 163). Den kapitalistiska produktionens strukturer vilar i grunden på socialt konstruerade distinktioner mellan människor - däribland rasifieringsprocesser - men governmentaliten (Foucault 2004) skapar en illusion av neutralitet och döljer dessa stratifieringar. Nyliberalismen uppfattas inte som "en uppsättning särintressen och politiska interventioner, utan som en form av ickepolitik" (Duggan 2003, 10). Detta skyler över rådande maktförhållanden, skapar det förtryck som nyliberalismen vilar på och formar kvinnors, rasifierade gruppers och andra minoriteters levda, vardagliga erfarenheter.

Ur detta perspektiv framstår det faktum att antidiskrimineringsstrategier implementeras parallellt med institutionellt förtryck inte som så paradoxalt som det först kan ge sken av. Det nyliberala värdesystemet underbygger på ett effektivt sätt privilegierade människors ignorans. Individualism och meritokrati förutsätter att lika möjligheter råder och avfärdar resursomfördelning som ett medel att stävja social ojämlikhet. Antidiskrimineringslagstiftningen blir ett sätt att skapa lika möjligheter genom att helt enkelt tillerkänna alla individer samma rättigheter. Men medan sådana regleringar kan vara användbara för att bekämpa vissa former av rasism lämnar de också utrymme för en normalisering 
av ojämlikheter inom samhället. Om antidiskrimineringslagar garanterar att vem som helst kan motsätta sig diskriminering så innebär det också att alla ansvarar för sin egen ställning på arbetsmarknaden och i samhället som helhet. Detta kapitel är en kritisk granskning av bristerna $i$ antidiskrimineringslagstiftningen och den tillhörande diskursen om lika möjligheter. Ett perspektiv som utgår från rasifierade arbetare inom äldreomsorgen belyser hur antidiskrimineringsambitionerna kan vara starka på policynivå, samtidigt som samhällets politiska ekonomi reproducerar allvarliga ojämlikheter som utgår från rasifierade och könsmässiga distinktioner.

Under 2013-14 registrerade Storbritanniens arbetsdomstolar 3064 fall som gällde rasdiskriminering (BBC 2015). Antalet fall minskade sedan regeringen infört ansökningsavgifter för rättsfall 2013; under 2009-10 registrerades 5700 fall (Ministry of Justice 2012). Diskrimineringsärenden hör till de dyraste fallen där ansökningsavgifterna kan uppgå till 1200 pund, att jämföra med exempelvis 410 pund för fall som gäller obetalda löner (Department for Business Innovation and Skills 2014). Till detta kommer att bara en mindre andel av fallen $i$ arbetsdomstolarna tas upp till rättegång: de flesta fall avgörs av The Advisory, Conciliation and Arbitration Service (33 procent under 2010-11), dras tillbaka (27 procent) eller läggs ner (13 procent) (Ministry of Justice 2012). Om de väl når rättegång har diskrimineringsfallen lägst andel fällande domar: 16 procent under 2010-11 (Renton 2013). I en artikel publicerad av The Institute of Race Relations (ibid.) frågar Renton varför det är så svårt att vinna rasdiskrimineringsfall, inte bara i jämförelse med fall som rör uppsägningar och lönefrågor, utan också i jämförelse med andra diskrimineringsfall, såsom könsdiskriminering (37 procent) och diskriminering av sexuella minoriteter (26 procent). Efter att ha granskat flera fallstudier menar han att domarna ofta utgår från att rasdiskriminering förutsätter rasistiska avsikter. Att enbart diskutera institutionell rasism inom ramen för politiska antidiskrimineringsstrategier - vilket är praxis i Storbritannien - är således inte tillräckligt för att rätten ska beakta dess betydelse i enskilda fall. Rasdiskriminering knyts ofta till förövarnas rasistiska uppsåt och rättsfall tenderar att kretsa kring att bevisa eller motbevisa rasistiskt uppsåt i stället för att klarlägga förekomsten eller frånvaron av diskriminering. 
I Frankrike grundades 2005 den statsfinansierade myndigheten för jämlikhet och bekämpande av diskriminering (Haute Autorité de lutte contre les discriminations et pour l'égalité, HALDE), efter krav från EU. Myndigheten har till uppgift att bistå offer för diskriminering och stödja deras rättsliga kamp i de fall då HALDE har granskat deras fall och kunnat konstatera att diskriminering har skett. Enligt siffror som myndigheten publicerade 2010 hade antalet ärenden ökat från 1410 under 2005 till 12467 under 2010. Ungefär hälften av dessa ärenden gällde anställningsfrågor, och i 28,5 procent av fallen mellan 2005 och 2009 nämndes "diskriminering grundad på etniskt ursprung" (HALDE 2010, 21). Rattansi (2011) noterar emellertid att denna nya myndighet tilldelades betydligt mindre resurser än den tidigare brittiska motsvarigheten, British Commission for Racial Equality. Dessutom existerade HALDE bara under några år innan den 2011 integrerades i en myndighet med ett bredare mandat, Défenseur des Droits (rättigheternas försvarare), som under ledning av en "ombudsman" också hade ansvar för barns rättigheter, medborgares rättigheter gentemot offentliga verksamheter samt etik och säkerhet. Nedläggningen av HALDE kritiserades hårt av gräsrotsorganisationer; det verkar som att offer för diskriminering har fått sämre tillgång till information och att rättsfall inte längre publiceras online. Tvärt emot HALDE:s tidigare rutiner är statistik rörande framgångsrika diskrimineringsfall inte tillgänglig.

Liksom i Storbritannien och Frankrike finns det i Spanien en djup klyfta mellan hur utbredd diskrimineringen är och hur ofta den tas upp i rätten, vilket har belysts i tidigare studier (Actis m.fl. 2003). Antidiskrimineringslagstiftning har införts först under det senaste decenniet, och den ekonomiska krisen har begränsat statens förmåga att implementera antidiskrimineringsprogram. Rådet för befrämjade av lika möjligheter och bekämpande av diskriminering på etniska eller rasmässiga grunder (El Consejo para la promoción de la igualdad de trato y no discriminación de las personas por el origen racial o étnico) som grundades 2007 registrerade exempelvis bara 167 fall av diskriminering under 2010 (Ministerio de Sanidad, Política Social e Igualdad 2011) och fick snart krympande anslag enligt en rapport som European Network Against Racism (ENAR) publicerade 2013 (Spitálszky 2013). ENAR betonar också att Spanien inte lyckats publicera en transparent 
databas med alla diskrimineringsfall, vilket gör det omöjligt att granska hur effektiv lagstiftningen varit (ENAR 2013).

Antidiskrimineringslagstiftningen mobiliseras i allmänhet $\mathrm{i}$ ett begränsat antal fall i alla de tre länderna. Denna översikt visar att ett fokus på individuella rättigheter tycks erbjuda begränsade möjligheter att bemöta djupt rotade ojämlikheter som kräver större social förändring. Antidiskrimineringslagstiftning har dessutom olika konsekvenser för olika individer, beroende på deras klass och könstillhörighet. De mest privilegierade av de rasifierade arbetarna, som exempelvis har tillräckliga resurser för att driva rättsprocesser, har bättre möjligheter att förlita sig på dessa lagar. Osynliggörandet av rasifieringsprocessernas bestående relevans i dagens samhälle, och deras sociala implikationer för rasifierade individer, gör det svårare att identifiera, förstå och utmana institutionell rasism. I det följande stycket belyser jag särskilda aspekter av den rasism som migranter och medlemmar ur etniska minoriteter som jobbar inom sjukvårdssektorn upplever på sin arbetsplats, och diskuterar varför vissa upplevelser utgör institutionell rasism.

\section{Maktförhållanden och vardagsrasism på arbetsplatsen}

En ansenlig andel av mina respondenter vittnade om att de har utsatts för rasism och diskriminering, av antingen vårdtagare, arbetskam rater eller ledningen inom äldreomsorgen: 41 procent i London, 47 procent $\mathrm{i}$ Paris och 44 procent i Madrid. Respondenterna hade skiftande erfarenheter av både öppna och förtäckta former av rasism. De fick utstå systematiska rasistiska kommentarer från vårdtagare, och några av dem blev även diskriminerade eller trakasserade av sina arbetskamrater och chefer. Individuella berättelser avslöjar också att olika former av rasism ofta utövas simultant. I sin etnografiska studie över svarta hushållsarbetare och hemsjukvårdare i Nederländerna beskriver Sabrina Marchetti mötena inom hemsjukvården som "scenarier av rasism" (2014, 151). Hennes beskrivningar av deltagarnas upplevelser avslöjar att rasistiska attityder från patienter och boende påverkade i stort sett alla rasifierade arbetare. Eftersom merparten av detta material samlades in utan att Marchetti ställde direkta frågor om rasism kan de fall då informanterna 
inte vittnade om rasistiska erfarenheter inte nödvändigtvis tolkas som att de inte mött rasism.

Genom att fokusera på fall av rasistiskt bemötande från kollegor och diskriminering eller trakasserier från chefer kopplar jag i denna empiriska del av kapitlet individuella interaktioner till en institutionell ordning i syfte att fördjupa förståelsen av hur politiska strategier och institutionella sammanhang hänger samman med rasistisk diskriminering och exkludering på arbetsplatsen så väl som med strategier för att hantera sådan rasism.

\section{Rasistiska attityder bland kollegor: Kränkande arbetsmiljöer}

Respondenter i Madrid och London hade erfarenheter av kollegors rasistiska attityder på arbetsplatsen. I Paris klagade inga av respondenterna över rasistiska attityder bland medarbetarna, vilket delvis kan bero på att rasifierade arbetare utgjorde en betydande majoritet av arbetskraften på de vårdhem där fältarbetena ägde rum (omkring 70-90 procent enligt de sjuksköterskor i arbetsledande position som jag intervjuade). Att möta samma typ av rasism från vissa vårdtagare kan ha skapat en solidaritet bland arbetarna. ${ }^{1}$

Kränkande kommentarer från kollegor till arbetare med migrantbakgrund utgjorde ett uppenbart uttryck för rasistiska hierarkier. Isabel, som hade påbörjat en masterutbildning i Filippinerna, ${ }^{2}$ kände sig djupt förolämpad av kollegornas kommentarer:

På mitt tidigare jobb har jag upplevt att det finns vissa människor som är ... du vet ... rasister. När jag började där sa dom, en av vårdarna frågade, eftersom jag läste en tidning i en boendes åsyn, så frågade hon mig: "Så du kan läsa engelska?" Jag svarade: "Ja, jag hade inte kunnat komma hit om jag inte kan läsa engelska." "Jaha, jag förstår"... och sedan använde jag fjärrkontrollen för att en av vårdtagarna bad mig slå på teven. "Jaså, du vet hur man använder den där?" Det är som att dom tror att jag är dum eller analfabet bara för att jag är utlänning. Jag vet inte ... dom bara nedvärderar dig. (Isabel, 37, Filippinerna, London) 
Isabel upplevde att hennes kollegor försökte förminska henne. Ofta uttryckte respondenterna likartade känslor inför mer förtäckta attityder som inte nödvändigtvis kom till uttryck i explicita interaktioner men inte desto mindre fick långtgående konsekvenser. Pedro, som var född i Spanien av föräldrar från Guinea, beskrev det spanska samhället som djupt rasistiskt och förklarade hur han hade tvingats lära sig att navigera bland sociala relationer som var genomsyrade av rasistiska fördomar:

Även om du hatar mig kommer jag att klara mig. Det är något jag lärde mig redan som liten pojke - att ignorera, kämpa på och fortsätta leva. Man kan inte göra något annat, det är inte värt det för det är inte ett möjligt alternativ. Man kan inte kämpa hela livet mot något så stort. Så jag ser det på jobbet, man ser en hel del av det. Vad som händer är att det blir upp till var och en hur man hanterar det. Om man är en person som inte kan ta det, och man inte kan hantera eller ignorera det för att kunna fokusera på vad som är verkligt viktigt ... ja, då kan man få problem. Men tyvärr så kommer dom aldrig att säga det till en. Mycket sällan säger dom något öppet så att man kan bemöta det, frågan är hur man bevisar det. Så dom säger: "Jag sa inget." Så det är bäst att bara ta det, skaka av sig det och förvandla det till något bra. (Pedro, 25, född i Spanien av föräldrar från Guinea, Madrid)

I Pedros berättelse är de rasistiska fördomarna diffusa, ständigt närvarande men sällan möjliga att bevisa. De genomsyrar så många delar av hans vardagliga sociala relationer att även om han är högst medveten om de rasistiska undertonerna i vissa attityder han möter så upplever han att han knappast kan göra något åt det. Fördomarna kommer inte till uttryck i förolämpningar eller aggressiva utspel utan i mindre uppenbara handlingar, vars betydelser dock lämnar föga utrymme för tvivel. Även Sameera, som citerades i början av detta kapitel, vittnar om hur svårt det är att hantera förtäckta former av rasistiska trakasserier:

Och när jag arbetade upplevde jag att dom inte tittade på mig när jag satt där, dom bara gick när jag kom in i personalrummet. Man sätter sig bredvid dom och dom flyttar på sig. Jag tänkte ... Vad hände? Jag tänkte att kanske luktar jag ... du vet? Kanske är det nåt fel med mig, 
kanske är mina kläder smutsiga. Jag som duschar varje dag ... Sakta, sakta kände jag av deras attityd. Nu börjar jag känna vad det här är - du vet. Och det var en tjej där som jag aldrig kommer att glömma, hur hon behandlade mig. Vad ska jag säga ... Det var som om jag inte fanns. (Sameera, 32, Mauritius, London)

Allteftersom Sameeras marginalisering blev mer uppenbar fick dessa rasistiska attityder starka konsekvenser för hennes välbefinnande. Hennes kollegors beteende var inte, så som det kan framstå, en passiv attityd utan utgjorde en aktiv form av mobbning. Detta slags interpersonella interaktion illustrerar rasistiska fördomar på individuell nivå. Sameeras kollegors attityd kan beskrivas som en form av aversiv rasism (Byrd 2011; Gawronski m.fl. 2008). Genom sådant beteende uttrycks negativa känslor gentemot en rasifierad person utan någon uttalad kritik mot egalitära värderingar. Pedros och Sameeras berättelser avspeglar hur manifestationer av rasism i interpersonella relationer idag tenderar att vara mindre uttalade på grund av att rasistiska uttryck har stigmatiserats i dominerande politiska och sociala diskurser och löper större risk att beivras. Offer för rasism är ofta osäkra på om och hur de kan bemöta en typ av rasism som inte uttrycks öppet. På grund av detta riskerar antidiskrimineringslagstiftning att inte kunna bemöta de sociala fenomen den är tänkt att hantera.

I Madrid klagade Claudia, som hade arbetat vid samma vårdhem $\mathrm{i}$ tio år, över de spanska kollegornas diskriminering av arbetare av latinamerikanskt ursprung (latinos):

På jobbet förekommer en del diskriminering. Dom som tar rast först är spanjorerna, och om latinos dyker upp: "Vad gör du här?” Så vad händer? Dom tar alltid rast först - spanjorerna. Det är bäst för dom. Och latinos får komma senare. (Claudia, 53, Peru, Madrid)

Rasistiskt beteende bland kollegorna borde få arbetsgivarna att ta sitt ansvar för att skapa en rättvis arbetsplats eftersom arbetsledarnas förbiseende är skadligt och skapar kränkande miljöer. Arbetsgivarna hade emellertid inte givit något stöd till de utsatta respondenterna i något av de nämnda fallen. I alla de fall då respondenterna anmälde tongivande, 
diskriminerande attityder bland kollegorna till sina chefer, blev cheferna delaktiga såtillvida att de antingen tolererade diskrimineringen eller slöt upp bakom den dominerande gruppen. Arbetare som hade blivit diskriminerade till förmån för en favoriserad grupp vågade inte protestera formellt eftersom de var rädda för vedergällning. Denna rädsla utgjorde en mycket vanlig avskräckande faktor från att förlita sig på antidiskrimineringslagstiftning.

\section{Diskriminering och trakasserier från chefer och anställda}

I detta avnitt behandlar jag respondenternas berättelser om upplevelser av rasism från handledare, chefer eller andra anställda (erfarenheter som liknar dem som undersköterskor i Sverige berättar om i Boréus m.fl., kapitel 9). I dessa berättelser samverkar prekära anställningar och arbetsvillkor med diskriminering, vilket ger upphov till särskilda erfarenheter och situationer. Min analys av det empiriska materialet visar att rasifiering får konkreta, materiella konsekvenser för arbetarna när olika regimer interagerar. I såväl Storbritannien som Frankrike och Spanien skapar migrations-, arbetslivs- och omsorgsregimer sårbarheter som drabbar arbetare som tillhör etniska minoriteter eller har migrationsbakgrund.

Olika omsorgsregimer och migrationsregleringar skapar viktiga skillnader i hur utsatta de som arbetar i omsorgssektorn är för arbetsgivarnas kränkningar. I Madrid gjorde det faktum att arbetarna ofta arbetade och levde i arbetsgivarnas hem deras situation mer prekär eftersom arbetarna var beroende av att arbetsgivarna upprätthöll deras rättsliga status. De flesta respondenterna arbetade inom hemsjukvård och hade bott i Spanien i åtminstone tio år. Merparten av dem kunde således få spanskt medborgarskap enligt postkoloniala regler för latinamerikanska migranter. I London riskerade de som hade studentvisum att förlora sin rättsliga status även om de fortsatte att arbeta inom sjukvårdssektorn eftersom de inte tjänade tillräckligt mycket. I Paris hade de flesta antingen ett långvarigt uppehållstillstånd (tio år) eller franskt medborgarskap. Ändå belyser respondenternas berättelser om chefers och medarbetares diskriminering varför politiska antidiskri- 
mineringsstrategier i praktiken har mycket begränsad betydelse när en stor andel av arbetskraften sitter fast i en segmenterad arbetsmarknad där de arbetar under prekära anställningsvillkor.

Till att börja med kan de sätt på vilka några chefer hanterade (eller underlät att hantera) diskriminering i sig utgöra rasistisk diskriminering under vissa omständigheter. Flera respondenter berättade till exempel att deras chef hade förflyttat dem till en annan enhet eller våning när de hade utsatts för rasistiska bemötanden från kollegor eller vårdtagare. Det sände fel signaler angående vem som kan hållas ansvarig och bidrog till att ytterligare marginalisera den utsatta arbetaren. I dessa fall omformade institutionella praktiker uttryck för individuella fördomar till en form av institutionell rasism i det att cheferna utnyttjade sin maktposition för att förstärka diskrimineringens konsekvenser. Sådana exempel illustrerar att det krävs en medvetenhet från chefernas sida för att kunna bemöta och rättsligt beivra rasism på arbetsplatsen. När Balibar kräver att "rasisterna måste förändra sig själva" (Balibar \& Wallerstein 1988, 29) förutsätter det att den dominerande gruppen, i detta fall cheferna och de övriga anställda, ändrar sitt eget beteende. Därför är det nödvändligt att analysera hur maktrelationer genomsyrar interaktionen mellan dessa grupper. I det följande stycket diskuterar jag hur samverkande faktorer såsom den kommersiella vårdens förutsättningar, migranternas skiftande status och villkoren för dem som bor hemma hos sin arbetsgivare skapar maktförhållanden som formar rasistiskt präglade mellanmänskliga relationer.

Att det vinstdrivande sammanhang som merparten av respondenterna arbetade inom förvandlar vårdtagare till konsumenter förstärker den spänning som finns i relationen mellan sårbara brukare och prekära arbetare. Den utsatthet som migrationspolitiken och arbetsmarknadens fragmentering skapade, som försvagade arbetarnas position, förvärrades av relationernas ekonomiska inramning. Bacar är tydlig med att detta sammanhang förstärker arbetarnas sårbarhet:

I vinstdrivande vårdhem är de boende kunder, "kunden är kung". Så kunderna premieras framför vårdare. Eftersom det är kunden som drar in pengar, medan arbetsgivaren betalar pengar för vårdaren. Han betalar för vårdaren i slutet av varje månad, medan kunderna betalar, 
så han föredrar kunderna som drar in pengar. Det är logiskt. Så om en vårdare har problem med en patient, boende eller en familjemedlem är det per automatik vårdaren som blir bestraffad. Kunden har alltid rätt. (Bacar, 35, Senegal, Paris)

Dessutom agerade cheferna emellanåt på sätt som var direkt diskriminerande; från orättvis arbetsfördelning till mobbning och stigmatisering. I många fall förekom flera av dessa former av diskriminering samtidigt. Som Cangiano med flera har visat är orättvis arbetsfördelning samt orättvis fördelning av arbetspass och semesterperioder vanliga former av diskriminering i vårdsektorn i Storbritannien (Cangiano m.fl. 2009, 137). Jade, som arbetade i Paris, klagade på att arbetspassen och de lediga dagarna fördelades godtyckligt:

Jag skulle säga att det är orättvist. Jag kan till exempel be om en dags ledighet, ena gången får jag det, andra gånger får jag avslag. Det enda jag vet är att det inte är rättvist. Semester, frånvaro, nej, det är inte rättvist. (Jade, 46, Elfenbenskusten, Paris)

Sådant ledarskap skapade dålig stämning och hade i skiftande utsträckning negativ inverkan på arbetarnas välbefinnande. Orättvis fördelning av arbetsuppgifter kunde få allvarliga hälsoeffekter för de arbetare som fick de fysiskt tunga uppgifterna. Migrantarbetare var dessutom tveklöst utsatta för särskilda former av diskriminering och exploatering till följd av den institutionella osäkerhet (Anderson 2010) som migrationspolitiken skapar inom den bredare gruppen av rasifierade arbetare. Ju mer beroende arbetarna var av sina arbetsgivare, exempelvis för att få boende eller att få sina arbetstillstånd styrkta, desto mer utsatta var de för kränkningar. Bristande språkkunskaper och begränsad kunskap om vilka rättigheter de hade bidrog till att ytterligare försämra deras situation. Isabels första arbetsgivare i Storbritannien försökte hålla kvar henne i ett arbete där hon utsattes för kränkningar: hon tvingades arbeta alla skift som passade arbetsgivaren, han gav henne bostad i ett rum i anslutning till vårdhemmet och betalade inte ut hennes lön. 
Arbetsmiljön är verkligen inte bra. Dom trycker ned och kränker oss eftersom dom vet att vi är nya och att vi är utlänningar. Så vi lämnade in vår avskedsansökan, men dom accepterade inte det. Dom ville att vi skulle stanna trots att vi har rätt att sluta om vi inte trivs, eller hur? Vi bad om tillstånd. Vi bad snällt om att inte behöva stanna här men dom accepterade inte det, så vi gav oss bara av. (Isabel, 37, Filippinerna, London)

Sameera utsattes också för kränkningar. Hon kände sig förtryckt på arbetsplatsen där hon blev mobbad men kände sig maktlös och oförmögen att bemöta denna behandling. Stigmat av att vara en migrant gick bortom hennes rättsliga status. Som Guillaumin (1972/2002, 247) skrev för många år sedan: "Varje individ som har varit utlänning, alienerad, förtryckt bär med sig spåren av det för all framtid, och hans/hennes nivå av integration och tillhörighet förblir oklar och utlämnad till den form av välvilja som den tysta majoritetens tolerans utgör." Sameera förväntade sig inte att hennes framtida brittiska medborgarskap skulle påverka hur hon uppfattades av chefer och kollegor på arbetsplatsen eller förändra deras kränkande attityder gentemot henne.

Och jag, som invandrare, jag kan inte ens öppna munnen, förstår du? Hur skulle jag kunna det? För dessa människor är mäktigare än jag [...] Trots att jag varit här i tio år nu, jag är gift, min status har förändrats. Imorgon ansöker jag om brittiskt medborgarskap och jag kommer att få det eftersom min man är britt. Men jag kommer ändå att betraktas som på en annan nivå, fattar du? På grund av min bakgrund, var jag kommer ifrån och min hudfärg [...] Detta är något som alltid, vad ska jag säga, finns inom mig, men jag kan inte prata om det. Ibland känns det som att jag bara vill tiga, och explodera. Men vad kan jag göra? Man är rädd, man gör sitt jobb. (Sameera, 32, Mauritius, London)

Migrantarbetarnas utsatta läge skapade utrymme för arbetsgivarnas godtycke, eftersom det var mycket osannolikt att deras handlingar skulle beivras på något sätt. I London talade Jenifer, som är född i England av asiatiska föräldrar, om hur utlänningar trakasserades på hennes arbetsplats: 
Och flera vittnen har berättat om hur hon [chefen] gick omkring på övervåningen, där mest filippinier och asiater arbetade och sa till arbetarna att: "Ni har tur som har era jobb här, annars skulle ni vara hemma. Om ni inte trivs där ni arbetar kan ni åka tillbaka till era hemländer.” (Jenifer, 24, Filippinerna, London)

Detta fall, där en chef trakasserade de anställda, handlar om mer än xenofobi. Det möjliggjordes av det utrymme för godtycke som uppstår när migrationspolitik förstärker ojämlikheten i relationen mellan arbetsgivare och anställda. Grace, som arbetade på samma vårdhem, framhöll att översitteriet var en konsekvens av ett maktförhållande:

Hon [chefen] beter sig inte på det sättet gentemot dom vita som arbetar där, som - du vet - bara kan säga upp sig och gå därifrån. Hon gör inte så mot dom. Det är skillnaden, att hon inte kan förolämpa dom på samma sätt. Hon gör så mot utlänningarna. (Grace, 61, Filippinerna, London)

De migrantarbetare som levde i vårdtagarnas hem i Madrid var mest utsatta för trakasserier och rasistiska tillmälen. Deras arbetsvillkor skapade en extrem obalans mellan arbetsgivare och anställd där den anställdes rättigheter var synnerligen kringskurna av å ena sidan migrationsregler och arbetsrättslagstiftning, å andra sidan arbetssituationens materiella villkor. Ett typiskt exempel är Lucias berättelse om hur hennes arbetsgivare, en av vårdtagarens familjemedlemmar, angrep henne när hon berättade att hon av hälsoskäl inte kunde följa med familjen till Mallorca som planerat:

Hon förolämpade mig. Hon sa att vi bara kom hit för att stjäla, att jag var en tjuv för att hon hade köpt en uniform åt mig. Hon hade köpt förnödenheter åt mig eftersom dom anställda som arbetade i huset inte åt där. Dom hade ett litet separat hus där hushållsarbetarna åt. Innan dom [arbetsgivarna] hade ätit klart fanns det arbete som behövde göras, men sen kunde vi gå till det mindre huset och äta något. Det var en väldigt svår situation där. (Lucia, 56, Nicaragua, Madrid) 
Maktobalansen mellan arbetsgivare och anställd tenderar att förstärkas under vissa omständigheter, särskilt när privatisering skapar ökade krav på att minska arbetskostnaderna eller när relationen mellan arbetsgivare och anställd utspelar sig i arbetsgivarens hemmiljö. Respondenternas vittnesmål om direkt diskriminering påminner om antidiskrimineringsstrategiers bristande inverkan på en verklighet där en stor andel av arbetsstyrkan är utlämnad till en segmenterad arbetsmarknad med begränsade rättigheter och prekära anställningsvillkor. Även när de har medborgarskap och legitim anställning har få migrantarbetare råd att på egen hand investera pengar och tid i långdragna rättsprocesser. Dessutom visar brittisk statistik att sådana rättsprocesser sällan är framgångsrika i Storbritannien, och frånvaron av statistik i Spanien och Frankrike vittnar om en brist på transparens och svagt politiskt intresse. Medan det finns avsevärda skillnader mellan antidiskrimineringslagstiftningens retorik och praktik i dessa länder skapar de strukturella sårbarheter som växer ur interaktionen mellan migrationsoch rasifieringsregimer, arbetsregimer och omsorgsregimer likartade vardagliga upplevelser bland de rasifierade arbetare som ingick i denna studie. Arbetarna bemötte emellertid dessa negativa erfarenheter med olika former av individuellt eller kollektivt motstånd. I det följande avsnittet tittar jag på kollektiva strategier för att hantera och bemöta arbetsgivarnas trakasserier och diskriminering.

\section{Kollektivt motstånd mot rasistiska praktiker}

Att söka stöd utanför arbetsplatsen är ännu svårare när de utsatta arbetarna är invånare utan medborgarskap, det vill säga befinner sig $\mathrm{i}$ en rättslig och ekonomisk position som ger dem svagare rättigheter än arbetare med medborgarskap (De Genova 2013; Standing 2011). På grund av skiftande sätt att hantera relationerna till näringslivet och olika syn på migrantarbetares plats inom arbetarklassen har fackföreningar hanterat migrantarbetare på olika sätt i olika delar av Europa. Forskning om fackförbunds motstånd mot att ta emot rasifierade medlemmar (Virdee 2000) och deras tvekan inför att se och bekämpa rasism på arbetsplatsen (Jefferys \& Ouali 2007) illustrerar fackföreningsrörelsens historiska ambivalens inför rasism. Merparten av deltagarna i denna studie var inte 
medlemmar i en fackförening när intervjuerna genomfördes: 56 procent i London, 93 procent i Paris och 85 procent i Madrid. I Paris nämndes inte fackföreningar i diskussionerna om hur rasism och diskriminering kan bemötas. Det kan ha berott på att de erfarenheter av rasism som respondenterna i Paris hade mestadels handlade om rasistiska attityder bland vårdtagare och tystades ned med hänvisning till att det hör till jobbet (Sahraoui 2018).

Det verkar som att de flesta arbetare i Madrid hanterade trakasserier genom att vända sig till informella stödgrupper och sällskap, medan fackföreningar fick kämpa hårt för att vara närvarande på den kvinnliga delen av arbetsmarknaden där många migranter arbetar. Fackföreningarnas svaga närvaro berodde delvis på att deras metoder för att organisera arbetarna var dåligt anpassade för denna grupp (de höll exempelvis möten vid tidpunkter då arbetarna inte kunde närvara och prioriterade frågor som inte svarade mot vårdarbetarnas behov) och delvis på att vårdarbetarna som jobbade i arbetsgivarnas hem var isolerade. Ofta uppstod sådana föreningar som en förlängning av en befintlig informell grupp som strävade efter att minska hushållsarbetarnas isolering. Sådana organisationer spelade en viktig roll i Madrid där det var vanligt att arbetarna bodde hos vårdtagarna. Victoria, som hade grundat en förening för sjukvårdsarbetare med migrantbakgrund, berättade att de hade kunnat ge stöd till migrantarbetare som hade blivit utkastade från de familjer de arbetade för, ibland efter att ha blivit förolämpade och kränkta:

Vi hade kollegor som hade det väldigt svårt. Dom fick höra "Vad gör du här? Åk hem till ditt eget land" [...] Dom lämnade sina jobb och var mycket deprimerade. Vi har fått hjälpa många kvinnor som dök upp och berättade: "Dom behandlade mig så här, dom sa så här till oss." Och jag: "Nej, du måste rycka upp dig. Det där är inte du, du måste fortsätta." Och eftersom vi alltid har haft turen att arbeta med professionella kollegor - vi har en kollega som arbetar som psykolog, andra som har gjort det. Så dom har hjälpt oss att få kvinnorna att förstå att det dom har fătt höra inte är sant. (Victoria, 54, Ecuador, Madrid) 
Mayra, som också kommer från Ecuador, gick med i en grupp för hushållsarbetare i Madrid som träffades två gånger i månaden. Dessa kontakter gav henne ett starkt stöd:

Vi har en förening, en grupp kvinnor där vi stärker oss själva genom att lära oss tekniker och knep för att kunna stå ut med arbetssituationen. Det är ingen annan som kan lära oss, utan det är de gemensamma erfarenheter vi alla delar som gör att vi tillsammans kan skapa metoder för att hantera vår situation och saker som påverkar oss på jobbet. (Mayra, 52, Ecuador, Madrid)

Sådant stöd var avgörande för arbetarnas välbefinnande, och även om dessa organisationer ibland också kunde bistå vid rättsprocesser var det inte deras huvudsakliga funktion. Medan fackföreningar teoretiskt kunde spela den rollen nämndes de sällan av respondenterna i Madrid och var inget betydande stöd när någon utsatts för trakasserier. Medlemmarna i den förening Mayra nämner var exempelvis ganska kritiska till fackföreningarna, som de uppfattade som föråldrade organisationer som var oförmögna att hantera de särskilda utmaningar som präglade de starkt kvinnodominerade sektorerna för hälsovård och hemarbete. En respondent som hade blivit utsatt för trakasserier i Madrid funderade på att vända sig till en fackförening, men fackföreningsrepresentanterna själva avrådde henne från att inleda en rättsprocess:

NS: Funderade du i denna situation på att exempelvis söka stöd från en fackförening?

Rita: Ja, javisst.

NS: Vad kunde de göra i den situationen?

Rita: Jag sa att jag var beredd att anmäla henne för trakasserier eftersom jag visste att facket skulle backa upp mig. Vad som hände var - det här är vad facket sa till mig - att om jag skulle ta fallet till domstol måste jag vara modig. Dom sa: "Om du tar det till domstol måste du vara modig, för den här kvinnan kommer att trakassera dig mer än du kan föreställa dig, hon kommer att fortsätta trakassera dig tills hon kan bevisa att du är arrogant, och hon kommer att vinna i stället för dig. Tar du risken att gå till domstolen?” Han sa att eftersom rättegången 
skulle ta åratal så kunde jag ha lämnat vårdhemmet men rättegången skulle ta ytterligare två, tre år, eller mer. Så jag sa: ”Nä, jag har inte kommit till den punkten att ... jag är inte så utsvulten att jag måste ta det till domstolen.” (Rita, 54, Ecuador, Madrid)

Denna berättelse visar att fall rörande rasistisk diskriminering är särskilt svåra att driva i domstol, till och med för fackföreningar. Att det finns en antidiskrimineringslag stärker i sig inte rasifierade arbetare, eftersom vägen till arbetsdomstolen är kantad av fallgropar. Fackföreningarnas motvilja mot att inleda rättsprocesser avspeglar en medvetenhet om hur begränsade de är. Samtidigt belyser det återigen att de flesta fall av diskriminering aldrig bestrids (åtminstone i rättslig bemärkelse) och därmed aldrig beivras.

Respondenterna i London beskrev fackföreningarna som ett potentiellt stöd, men i praktiken sökte inga av dem hjälp från en fackförening, i vissa fall trots att de hade gått med i en fackförening på grund av att de haft problem på jobbet. Isabel, sjukvårdsarbetaren från Filippinerna som blev kränkt på sin första arbetsplats i Storbritannien, trodde att en fackförening hade kunnat ge bra stöd om hon hade bett om det:

Eftersom rasism och mobbning är ett stort problem i det här landet så accepterar dom det inte. Det är inte ett brott, men det är en stor sak för dom [...] Jag kunde ha fått stort stöd från facket om jag varit medlem [...] eftersom det jag upplevt här verkligen är rasism, mobbning och kränkningar. (Isabel, 37, Filippinerna, London)

I praktiken ställdes fackföreningarna inför liknande svårigheter som de gjort i Madrid, trots att Storbritannien har strängare bestämmelser. Arbetarna upplevde att det var svårt att bevisa att diskriminering hade förekommit, särskilt när det rörde sig om förtäckta former av rasism. Dessutom var många respondenter i Storbritannien rädda för att ledningen skulle se det som negativt om de gick med i en fackförening. När det kunde bli aktuellt att ta hjälp av fackföreningar för att bemöta fall av diskriminering växte denna oro. En rädsla för att hennes framtida situation skulle förvärras om hon framförde en anklagelse om diskriminering avskräckte Sameera från att söka stöd från facket: 
NS: Och tog du kontakt med facket?

Sameera: Nej, jag gjorde inte det eftersom jag tänkte att jag hade löst problemet. Tack och lov så gick det bra och jag behövde inte blanda in facket, för det hade kunnat ligga mig i fatet. Om något inte kan lösas över huvud taget så blandar jag in dom, men annars ... För tillfället så är det okej. (Sameera, 32, Mauritius, London)

Kommersialiseringen av fackföreningarnas tjänster, särskilt i Storbritannien, bidrog till att undergräva arbetarnas förtroende för fackföreningar: om medlemskap i en fackförening var en fråga om vinst och förlust för fackföreningen (och för arbetarna) så uppfattades det som mindre troligt att en fackförening skulle stödja dyra och osäkra rättsprocesser. Denna paradox var mest framträdande i Storbritannien: trots en välutvecklad antidiskrimineringslagstiftning som omfattar en mängd former av diskriminering begränsas möjligheterna att väcka talan i arbetsdomstolen av strukturella egenheter i Storbritanniens arbetsrätt, såsom svagare anställningsskydd än i andra europeiska länder, dyra rättsprocesser och en bristande vilja från fackföreningar att driva diskrimineringsfall eftersom chanserna att vinna är små. I sina försök att stödja kollegor som trakasserades av chefen på vårdhemmet där de arbetade såg Grace ingen större potential hos fackföreningarna:

Alla tjänar pengar, till och med facken tjänar pengar ibland. Dom samlar in medlemsavgifter men dom stöder dig inte när du behöver dom. Dom samlar in pengar. Allt är business idag. Så när det gäller att driva fall, när det gäller att lägga så mycket pengar på att kämpa för din rätt. Tack och hej, dom vill inte ha dig. [...] Om du inte är en stark person som kan stå ut med alla dessa besvär och bekymmer, glöm det. För det är en mycket långdragen process och du behöver starka bevis för att bevisa det. (Grace, 61, Filippinerna, London)

När arbetare utsätts för diskriminering och kränkningar har de ofta svårt att åberopa sina rättigheter, även i synbart välutvecklade rättsstater såsom Storbritannien, där dyrbara rättsprocesser och prekära arbetsvillkor kraftigt begränsar arbetarnas möjligheter att driva sådana fall. Rådande maktförhållanden gör det svårt för arbetare att utmana chefer 
och arbetsgivare. Svårigheten att bevisa diskriminering och trakasserier bidrar till problemet, och till oron inför att inleda en fruktlös process och därmed riskera att utsättas för ytterligare kränkningar.

\section{Slutsatser}

I detta kapitel har jag analyserat hur lika former av rasism och diskriminering och de skiftande strategierna för att hantera dem hänger samman med en bredare institutionell rasism. Situationer där arbetare trakasserats och kränkts av sina kollegor ger prov på vanligt förekommande uttryck för rasism och diskriminering och visar hur detta påverkar arbetarnas välbefinnande.

I den första delen av kapitlet visade jag att respondenternas upplevelser av rasism var kopplade till maktförhållanden på arbetsplatsen och belyste den roll chefer och arbetsgivare spelade i olika situationer. Mobbning eller trakasserier från kollegor har inte resulterat i disciplinära eller rättsliga åtgärder i något enda av de fall som ingår i denna studie.

I den andra delen visade jag att direkt diskriminering eller trakasserier från chefer underströk hur migrationsregimer, omsorgsregimer och arbetslivsregimer interagerade och skapade en ökad prekaritet som bidrog till kränkningar på arbetsplatsen. Migrantarbetare var mer utsatta för direkta trakasserier från sina chefer, en konsekvens inte bara av det fundamentalt ojämlika förhållandet mellan migranter och icke-migranter utan också av rasifieringsprocesser och bristande rättigheter för de som saknar medborgarskap.

På det hela taget illustrerar detta kapitel hur arbetslivs- och migrationsregimer definierar arbetares rättigheter och exponerar dem för rasistisk diskriminering, trakasserier och kränkningar. Det är svårt att hantera dessa situationer och ingen enskild strategi kan på egen hand förbättra arbetares villkor i alla dessa avseenden. Antidiskrimineringslagstiftning tycks ha en mycket begränsad betydelse för prekära arbetare: trots de otaliga vittnesmål som respondenterna i denna studie avgav hade ingen av dem förlitat sig på antidiskrimineringslagstiftning. Det stora flertalet av dessa fall beivras aldrig, vilket antyder att det är svårt att åtgärda strukturellt ojämlika maktförhållanden genom individuella rättsfall. Dessutom skapas eller förstärks kränkande situationer ofta av 
det godtycke som migrations- och anställningspolitik ger utrymme för. Därför riskerar en överskattning av antidiskrimineringslagstiftningens betydelse att likställa antirasism med offentliga antidiskrimineringsstrategier i stället för att analysera den politiska ekonomin bakom de materiella förutsättningar som göder rasism och diskriminering. Att bekämpa rasism och rasistisk diskriminering kan inte enbart vila på antidiskrimineringslagstiftning. Svagt anställningsskydd och de ojämlika maktförhållanden det skapar försämrar förutsättningarna för att hålla en arbetsgivare ansvarig för trakasserier. Möjligheterna till integration för arbetare som har migrantbakgrund eller tillhör etniska minoriteter kräver i grund och botten att arbetarnas ställning stärks genom att anställningsskyddet förbättras, migrantarbetarnas situation blir mindre prekär och ökat administrativt och ekonomiskt stöd gör det lättare att förlita sig på rättssystemet.

\section{Noter}

1 Det är viktigt att notera att dessa data inte innebär att rasistiska attityder inte kan uppstå bland rasifierade arbetare. Rasifieringsprocesser är mångfacetterade och skapar klyftor som lika väl kan manifesteras mellan rasifierade arbetare.

2 En skiftande men alltjämt signifikant andel av respondenterna med migrantbakgrund var formellt överkvalificerade: 8 av 10 migranter i London, nästan hälften i Paris och en tredjedel i Madrid. För en analys av överkvalifikation inom denna studie, se Sahraoui 2019.

\section{Referenser}

Actis, W., Pereda C. \& Ángel de Prada, M. (2003) Experiencias de Discriminación de Minorías Étnicas en España. Madrid: Colectivo Ioé. URL, hämtad juli 2018: http:// www.colectivoioe.org/uploads/edb969a5b5bb4f6aaf3f9afb865cf396533d9315.pdf.

Anderson, B. (200o) Doing the dirty work? The global politics of domestic labour. London: Palgrave Macmillan.

Anderson, B. (2010) "Migration, immigration controls and the fashioning of precarious workers", Work, Employment \& Society 24(2):300-317.

Anthias, F. \& Yuval-Davis N. (1992) Racialized boundaries: Race, nation, gender, colour and class and the anti-racist struggle. London \& New York: Routledge.

Aspinall, P.J. (2002) "Collective terminology to describe the minority ethnic population: The persistence of confusion and ambiguity in usage", Sociology 36(4):803-816.

Balibar, E. \& Wallerstein, I.M. (1988) Race, nation, classe: les identités ambiguës. Paris: Ed. La Découverte. 
BBC (2015) "Are race discrimination laws still needed in the workplace?" URL, hämtad juli 2018: http://www.bbc.com/news/uk-31856147.

Boyatzis, R.E. (1998) Transforming qualitative information: Thematic analysis and code development. Thousand Oaks, London \& New Delhi: Sage.

Byrd, C. (2011) "Conflating apples and oranges: Understanding modern forms of racism", Sociology Compass 5(11):1005-1017.

Cangiano, A., Shutes, I., Spencer, S. \& Leeson, G. (2009) Migrant care workers in ageing societies: Research findings in the United Kingdom. Report. Oxford: COMPAS, University of Oxford.

Carmichael, S. \& Hamilton, C.V. (1967/1992) Black Power. The Politics of Liberation. New York: Vintage Books.

De Genova, N. (2013) "Spectacles of migrant 'illegality': the scene of exclusion, the obscene of inclusion", Ethnic and Racial Studies 36(7):1180-1198.

Delphy, C. (2013) L'ennemi principal. Economie politique du patriarcat. Paris: Editions Syllepse.

Department for Business Innovation and Skills. (2014). Findings from the survey of tribunalemployment applications 2013. Research series no. 177. Hämtad augusti 2018: https://assets.publishing.service.gov.uk/government/uploads/system/ uploads/attachment_data/file/316704/bis-14-708-survey-of-employment-tribunal-applications-2013.pdf

Duggan, L. (2003) The twilight of equality. Neoliberalism, cultural politics and the attack on democracy. Boston: Beacon Press Books.

ENAR (2013) Racism and related discriminatory practices in employment in Spain. http://www.enar-eu.org/IMG/pdf/spain.pdf.

Esping-Andersen, G. (1990/2013) The three worlds of welfare capitalism. Hoboken, NJ: John Wiley \& Sons.

Federici, S. (2012) Revolution at Point Zero: Housework, reproduction, and feminist struggle. New York: PM Press.

Folbre, N. (2012) "Should women care less? Intrinsic motivation and gender inequality", British Journal of Industrial Relations 50(4):597-619.

Foucault, M. (2004) Naissance de la biopolitique. Cours au Collège de France 1978-1979. Paris: Seuil/Gallimard.

Fraser, N. (2016) "Contradictions of capital and care", New Left Review JulyAugust 100:99-117.

Froy, F. \& Pyne, L. (2011) "Ensuring labour market success for ethnic minority and immigrant youth". OECD Local Economic and Employment Development (LEED) Working Papers, 2011/o9, Paris: OECD Publishing.

Gawronski, B., Peters. K.R., Brouch, P.M. \& Strack, F. (2008) "Understanding the relations between different forms of racial prejudice: a cognitive consistency perspective", Personality \& Social Psychology Bulletin 34(5):648-665.

Gilroy, P. (1987/2002) There ain't no black in the Union Jack. London: Routledge. Guillaumin, C. (1972/2002) L'idéologie raciste. Paris: Editions Folios Essais.

HALDE (2010) Rapport Annuel HALDE 2010. Paris: La Documention Française. Hämtad juli 2018: http://www.ladocumentationfrancaise.fr/var/storage/rapports-publics/114000234.pdf.

Hall, S. (1978) "Racism and reaction". I Five views of multi-racial Britain. London: Commission of Racial Equality. 
Headley, C. (200o). "Philosophical Approaches to Racism: A Critique of the Individualistic Perspective". Journal of Social Philosophy, 31(2):223-257.

Ikuenobe, P. (2010) "Conceptualizing racism and its subtle forms", Journal for the Theory of Social Behaviour 41:(2):161-181.

Jefferys, S. \& Ouali, N. (2007) "Trade unions and racism in London, Brussels and Paris public transport", Industrial Relations Journal 38(5):406-422.

Lentin, A. \& Titley, G. (2011) The crises of multiculturalism: Racism in a neoliberal age. New York: Zed Books Ltd.

León, M. (2010) "Migration and care work in Spain: The domestic sector revisited", Social policy and society 9(3):409-418.

Lutz, H. (red.) (2008) Migration and domestic work: A European perspective on a global theme. Aldershot: Ashgate.

Marchetti, S. (2014) Black girls. Migrant domestic workers and colonial legacies. Leiden, Boston: Brill.

Martiniello, M. (2013) Penser l'ethnicité. Identité, culture et relations sociales. Liège: Presses Universitaires de Liège.

McCall, L. (2005) "The complexity of intersectionality", Journal of Women and Culture in Society 30(3):1771-1800.

Miles, R. (1993) Racism after "race relations". London: Routledge.

Ministerio de Sanidad, Política Social e Igualdad (2011) Informe anual sobre la situación de la discriminación y la aplicación del principio de igualdad de trato por origen racial o étnico en España. Madrid. Hämtad juli 2018: http://www. msssi.gob.es/ssi/igualdadOportunidades/docs/2010_Informe_Anual_Consejoigualdad_Accesible.pdf.

Ministry of Justice (2012) Employment Tribunals and EAT Statistics, 2011-12. Hämtad juli 2018: https://www.gov.uk/government/uploads/system/uploads/ attachment_data/file/218497/employment-trib-stats-april-march-2011-12.pdf.

Pardini, B. (2013). Diagnostic emploi formation relatif aux aides-soignants, aides médico-psychologiques et auxiliaires de vie sociale. Paris: Défi Métiers. http:// www.defi-metiers.fr/sites/default/files/docs/rapports-etudes/diagnostic_emploi_ formation_as_amp_avsl_o.pdf.

Rass, C. \& Wolff, F. (2018) "What is in a migration regime? Genealogical approach and methodological proposal". I A. Pott, C. Rass \& F. Wolff (red.), Was ist ein Migrationsregime? What is a migration regime?. Osnabrück: Springer VS.

Rattansi, A. (2011) Multiculturalism: A very short introduction. Oxford: Oxford University Press.

Renton, D. (2013) "Culture of disbelief? Why race discrimination claims fail in the employment tribunal". http://www.irr.org.uk/news/culture-of-disbelief-why-race-discrimination-claims-fail-in-the-employment-tribunal/.

Roy, O. (2008) La sainte ignorance. Paris: Seuil.

Sahraoui, N. (2018) "De la segmentation du marché du travail comme discrimination structurelle aux expériences individuelles de discriminations racistes", Les Mondes du Travail, $\mathrm{nr} 21$.

Sahraoui, N. (2019) Racialised workers and European older-age care. From care labour to care ethics. Cham: Palgrave Macmillan.

Samers, M. (2008) "At the heart of 'migration management': immigration and labour markets in the European Union". I C. Gabriel \& H. Pellerin (red.) Gover- 
ning international labour migration: current issues, challenges and dilemmas. London \& New York: Routledge.

Scrinzi, F. (2013) Genre, migrations et emplois domestiques en France et en Italie. Paris: Editions Petra.

Sivanandan, A. (1985) "RAT and the degradation of black struggle", Race \& Class 26(4):1-33.

Smith, D.E. (2005) Institutional ethnography: A sociology for people. Oxford: Altamira Press.

Spitálszky, A. (2013) Racism and related discriminatory practices in employment in Spain. European Network Against Racism. URL: http://www.enar-eu.org/ IMG/pdf/spain.pdf.

Standing, G. (2011) The precariat: The new dangerous class. London: Bloomsbury Academic.

Tronto, J.C. (2011) "Privatizing neo-colonialism: Migrant domestic care workers, partial citizenship and responsibility". I M.H. Dahl, M. Keränen \& A. Kovalainen (red.) Europeanization, care and gender. London: Palgrave Macmillan.

Williams, F. (2012) "Converging variations in migrant care work in Europe", Journal of European Social Policy 22(4):363-376.

Williams, F. (2014) "Making connections across the transnational political economy of care". I B. Anderson \& I. Shutes (red.) Migration and care labour theory, policy and politics. London: Palgrave Macmillan.

Virdee, S. (2000) "A marxist critique of black radical theories of trade-union racism", Sociology 34(3):545-565.

Yinger, J.M. (1981) "Towards a theory of assimilation and dissimilation", Ethnic Studies 4(3):249-264.

Tillkännagivanden: Denna forskning har finansierats av projektet $\mathrm{FP}_{7}$-PEOPLE2012-ITN, "Changing Employment" (The changing nature of employment in Europe in the context of challenges, threats and opportunities for employees and employers", projektnummer 31732). En annan version av detta kapitel publicerades i Nina Sahraoui (2019), Racialised workers and european older-age care. From care labour to care ethics. Cham: Palgrave Macmillan. Kapitlet är översatt till svenska av Martin Fredriksson. 